\title{
COL2A1 Gene
}

National Cancer Institute

\section{Source}

National Cancer Institute. COL2A1 Gene. NCI Thesaurus. Code C75315.

This gene plays a role in both skeletal development and cartilage structure. 